\title{
PENGARUH VARIASI LAMA PEMAPARAN ASAP ROKOK TERHADAP PROFIL KADAR MALONDIALDEHIDA PADA HEWAN COBA
}

\author{
Wahyu Armadiyanti*, Lizma Febrina, Hajrah, Muhammad Amir Masruhim
}

\author{
Laboratorium Penelitian dan Pengembangan Kefarmasian "Farmaka Tropis", \\ Fakultas Farmasi, Universitas Mulawarman, Samarinda, Indonesia \\ *Email: yantiwahyu80@gmail.com
}

\begin{abstract}
Malondialdehyde (MDA) is a compound that can describe the activity of free radicals in the cell and used as an indicator of oxidative stress due to free radicals. Cigarette smoke is one source of exogenous free radicals that can cause an increase levels of free radicals. This study aims to determine the effect of exposure to cigarette smoke on the profile of Malondialdehyde (MDA) levels in the body. The experimental animals were 20 divided into 4 groups, namely the normal control group and the experimental group, where the experimental group was divided into 3 groups based on the time variation of exposure are 7 days, 14 and 21 days. This study uses the method of TBARS (Thiobarbituric Acid Reactive Substances) measured by a UV-Vis spectrophotometer at $\lambda=531 \mathrm{~nm}$. The result of this research is MDA levels in the experimental group increased. The time of exposure to cigarette smoke is directly proportional to MDA levels where the longer the exposure time has higher the MDA level. The result of level MDA in experimental group are 0,904 $\mathrm{nmol} / \mathrm{mL}, 1,252 \mathrm{nmol} / \mathrm{mL}$ dan $1,87 \mathrm{nmol} / \mathrm{mL}$.
\end{abstract}

Keyword: Malondialdehyde, Cigarette smoke, mouse

\begin{abstract}
ABSTRAK
Malondialdehida (MDA) adalah senyawa yang dapat menggambarkan aktivitas radikal bebas di dalam sel sehingga dijadikan sebagai salah satu petunjuk terjadinya stres oksidatif akibat radikal bebas. Asap rokok merupakan salah satu sumber radikal bebas eksogen yang dapat menyebabkan peningkatan kadar radikal bebas. Penelitian ini bertujuan untuk mengetahui pengaruh lamanya paparan asap rokok terhadap profil kadar Malondialdehida (MDA) dalam tubuh. Hewan coba berjumlah 20 dibagi menjadi 4 kelompok yaitu kelompok kontrol normal dan kelompok eksperimen, dimana kelompok eksperimen dibagi menjadi 3 kelompok berdasarkan variasi waktu lama pemaparan yaitu 7 hari,14 dan 21 hari. Penelitian ini menggunakan metode TBARS (Thiobarbituric Acid Reactive Substances) yang diukur dengan spektrofotometer UV-Vis pada $\lambda=531 \mathrm{~nm}$. Hasil dari penelitian ini yaitu kadar MDA pada kelompok eksperimen mengalami peningkatan.Hasilnya menunjukkan semakin lama waktu pemaparan maka kadar MDA semakin tinggi.Kadar MDA pada kelompok paparan 7, 14 dan 21 hari berturut-turut yaitu $0,904 \mathrm{nmol} / \mathrm{mL}, 1,252 \mathrm{nmol} / \mathrm{mL}$ dan $1,87 \mathrm{nmol} / \mathrm{mL}$.
\end{abstract}

Kata Kunci: Malondialdehida, asap rokok, tikus 
DOI: https://doi.org/10.25026/mpc.v8i1.300

\section{PENDAHULUAN}

Dewasa ini masalah mengenai radikal bebas dan antioksidan telah menjadi hal yang popular di dunia kesehatan. Radikal bebas dikenal sebagai pemicu atau penyebab terjadinya penyakit sedangkan antioksidan adalah senyawa yang dapat menangkal atau meredam dampak negatif radikal bebas. Berbagai faktor dapat menjadi penyebab terbentuknya radikal bebas baik faktor secara internal dan faktor eksternal. Radikal bebas dapat berasal dari dalam tubuh contohnya berasal dari proses oksidasi makanan dan olahraga yang berlebih, sedangkan faktor dari luar yaitu berasal dari pencemaran lingkungan, asap kendaraan, bahan tambahan makanan, pestisida dan rokok.

Telah banyak penelitian yang membuktikan bahwa rokok dapat menjadi sumber salah satu penyebab peningkatan radikal bebas. Asap rokok merupakan salah satu sumber radikal bebas eksogen. Radikal bebas memiliki sifat reaktivitas tinggi, karena kecenderungan menarik elektron dan dapat mengubah suatu molekul menjadi suatu radikal oleh karena hilang atau bertambah satu elektron pada molekul lain. Radikal bebas akan merusak molekul yang elektronnya ditarik oleh radikal bebas tersebut sehingga menyebabkan kerusakan sel, gangguan fungsi sel, bahkan kematian sel $^{1}$. Berdasarkan penelitian yang telah dilakukan Brian (2013) menyimpulkan bahwa terdapat perbedaan antara kadar MDA serum kelompok bukan perokok dan perokok sedang berat serta kadar MDA serum kelompok perokok ringan dan perokok sedang-berat dan tidak terdapat perbedaan antara kadar MDA serum pada kelompok bukan perokok dan perokok ringan.

\section{Malondialdehida}

(MDA)

merupakan metabolit hasil peroksidasi lipid oleh radikal bebas. Senyawa ini merupakan biomarker peningkatan kadar radikal bebas ${ }^{3}$. Kadar MDA yang tinggi menunjukkan jumlah radikal bebas yang tinggi pula di dalam tubuh dan menunjukkan adanya proses oksidasi dalam membran sel kemudian MDA dapat berikatan dengan berbagai molekul biologis seperti protein, asam nukleat, dan amino fosfolipid secara kovalen sehingga dapat menyebabkan terjadinya kerusakan lokal dan disfungsi organ tertentu. Berdasarkan penelitian yang telah ada yang lebih membahas efek dari asap rokok terhadap kadar MDA maka perlu dilakukan penelitian untuk mengetahui pengaruh variasi waktu lamanya pemaparan asap rokok terhadap profil kadar MDA pada tikus putih.

\section{METODE PENELITIAN}

Alat

Box induksi kaca, mikropipet, gunting bedah, holder, hot plate, sentrifuge, spektrofotometer UV-Vis, timbangan analitik, timbangan hewan.

\section{Bahan}

Asam asetat glacial, aquadest, Asam klorida, asam tiobarbiturat (TBA), kapas, rokok filter, tabung effendorf, asam trikloro asetat (TCA), dan Tetra metoksi propana (TMP), etanol $70 \%$.

\section{Persiapan hewan coba}

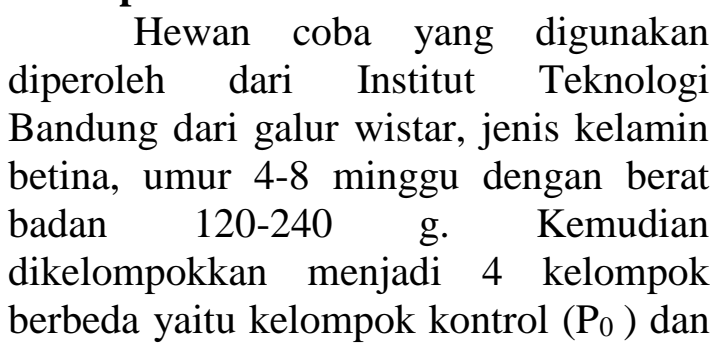


kelompok eksperimen. Kelompok eksperimen dibagi menjadi 3 kelompok berdasarkan variasi waktu lama pemaparan yaitu 7 hari $\left(\mathrm{P}_{1}\right) 14\left(\mathrm{P}_{2}\right)$ dan $21\left(\mathrm{P}_{3}\right)$ Diberikan pakan standar berupa pelet dan minuman standar berupa air minum secara rutin dan teratur serta diperhatikan kebersihan kandang serta penggantian sekam setiap 3 hari sekali. Hewan coba tidak diberikan perlakuan selama 2 minggu pertama sebagai waktu untuk beradaptasi di lingkungan yang baru.

\section{Pemaparan Bahan Uji}

Disiapkan bahan uji, berupa asap dari rokok jenis rokok filter. Dimasukkan hewan coba dalam box induksi kaca yang berukuran $38,5 \times 28,5 \times 22,5 \mathrm{~cm}$ dan dialirkan asap dari chamber rokok. Proses pemaparan dilakukan setiap pagi dan sore hari dengan menggunakan asap dari 3 batang rokok dan lamanya pemaparan disesuaikan dengan kelompok waktu pemaparan.

\section{Pengambilan Sampel Darah}

Diusap bagian ekor tikus dengan kapas yang telah dibasahi dengan etanol $70 \%$ lalu dipotong sedikit ujung ekor tikus. Diusap secara perlahan dari pangkal hingga ujung ekor. Ditampung 0,5 $\mathrm{mL}$ darah yang keluar dan dikumpulkan dalam tabung effendorf kemudian disentrifugasi dengan kecepatan 3000 rpm selama 10 menit. Diambil supernatant untuk pengujian tahap selanjutnya. Sampel darah hewan coba diambil sebelum dan setelah pemaparan.

\section{Pembuatan Kurva Baku Tetra Metoksi Propan (TMP)}

Dibuat larutan TMP dengan konsentrasi $20 \mathrm{nmol} / \mathrm{mL}$ sebagai standar dalam pengujian kadar MDA sampel. Diambil dari larutan stok tersebut sebanyak 0,$65 ; 1,25 ; 2,5 ; 5$ dan 10 ppm. Lalu dimasukkan $0,5 \mathrm{~mL}$ ke dalam 5 buah tabung reaksi yang berbeda.
Ditambahkan Asam Trikloroasetat (TCA) $20 \%$ sebanyak $1 \mathrm{~mL}$ ke dalam setiap tabung reaksi, lalu dikocok hingga homogen. Ditambahkan Aquadest ke dalam setiap tabung reaksi hingga volumenya mencapai $2 \mathrm{~mL}$. Ditambahkan reagen Asam Tiobarbiturat (TBA) 0,67\% sebanyak $1 \mathrm{~mL}$ ke dalam setiap tabung reaksi, dikocok kembali hingga homogen. Digunakan larutan yang sama tanpa TMP sebagai blanko. Dimasukkan semua tabung reaksi ke dalam pemanas air pada suhu $100^{\circ} \mathrm{C}$ selama 10 menit, lalu didinginkan. Diukur absorbansi pada $\chi=$ $531 \mathrm{~nm}$ dengan menggunakan spektrofotometer UV-Visibel dan dibuat kurva kalibrasi.

\section{Pengukuran Kadar MDA Sampel}

Dipipet $1 \mathrm{~mL}$ supernatan (plasma) dari semua kelompok, baik kelompok uji maupun kontrol ke dalam tabung reaksi. Ditambahkan TCA 20\% sebanyak $1 \mathrm{~mL}$. Disentrifugasi dengan kecepatan 3000 rpm selama 5 menit. Dipipet $1 \mathrm{~mL}$ supernatan dan ditambahkan dengan 1 mL TBA $0,67 \%$. Diukur absorbansi dari warna yang terbentuk pada $\chi=531 \mathrm{~nm}$ dengan menggunakan spektrofotometer UV-Visibel. Dihitung kadar MDA sampel dengan menggunakan kurva kalibrasi dari TMP.

\section{HASIL DAN PEMBAHASAN}

Analisis kadar MDA dilakukan dengan menggunakan serum darah tikus yang diukur menggunakan spektrofotometer dengan metode TBARS. Metode TBARS merupakan metode yang digunakan untuk mengukur oksidasi lipid. Angka TBA merupakan parameter yang digunakan unuk pengukuran besar kerusakan lipida karena reaksi oksidasi. Metode TBARS didasarkan pada pembentukan warna merah antara MDA yang merupakan produk oksidasi sekunder dengan asam 2tiobarbiturat (TBA) dan absorbansinya diukur menggunakan spektrofotometer ${ }^{3}$. 
Sebelum diberikan perlakuan semua hewan uji diadaptasikan selama dua minggu untuk menghindari risiko timbulnya stress selama proses pengiriman serta menyeragamkan pola makan ataupun pola hidup dengan lingkungan baru. Sumber radikal bebas dalam pengujian ini adalah rokok filter yang berjumlah 3 batang setiap pagi dan sore hari dengan lamanya waktu pemaparan sesuai dengan kelompok waktu pengujian. Pengamatan yang dilakukan menunjukkan perubahan hewan uji setelah diberi paparan asap rokok. Perubahan yang terjadi menunjukkan terjadinya stress pada hewan uji. Perubahan yang terjadi meliputi dehidrasi yang ditandai dengan keaktifan hewan uji yang menurun, dan detak jantung yang lebih cepat.

Adapun hasil penelitian dapat dilihat pada tabel 1 dan gambar 1 .

Tabel 1 Rata-Rata absorbansi kadar MDA tikus

\begin{tabular}{ll}
\hline Kelompok & Rata-rata $\pm \mathrm{SD}$ \\
\hline Kontrol $\left(\mathrm{P}_{0}\right)$ & $0.155 \pm 0.030$ \\
Paparan 7 hari $\left(\mathrm{P}_{1}\right)$ & $0.191 \pm 0.009$ \\
\hline Kontrol $\left(\mathrm{P}_{0}\right)$ & $0.157 \pm 0.032$ \\
Paparan 14 hari $\left(\mathrm{P}_{2}\right)$ & $0.231 \pm 0.084$ \\
\hline Kontrol $\left(\mathrm{P}_{0}\right)$ & $0.157 \pm 0.030$ \\
Paparan 21 hari $\left(\mathrm{P}_{3}\right)$ & $0.303 \pm 0.129$ \\
\hline
\end{tabular}

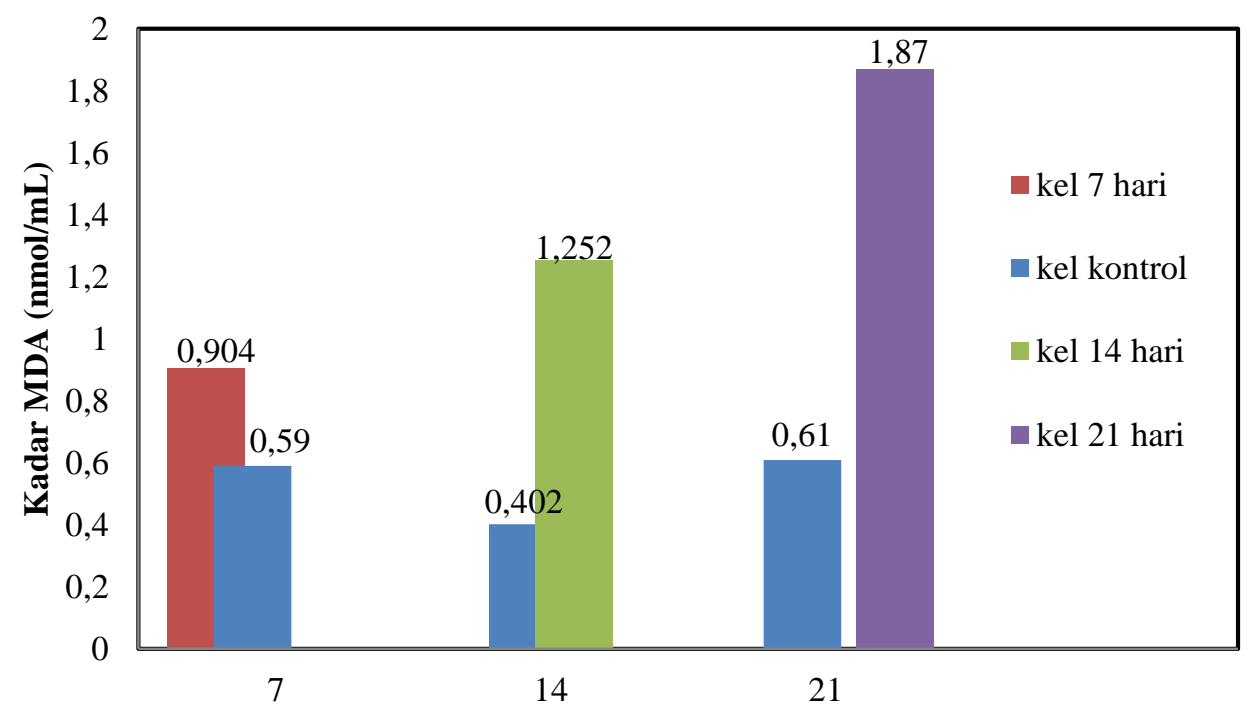

Hari Ke

Gambar 1 Kadar MDA pada tikus

Berdasarkan data pada grafik dan tabel diatas pada kelompok $\mathrm{P}_{1}$ dibandingkan dengan kelompok $\mathrm{P}_{0}$ memiliki kadar dan rata-rata yang lebih tinggi dimana rata-rata pada kelompok $\mathrm{P}_{1}$ yaitu 0,191 dengan kadar $0,904 \mathrm{nmol} / \mathrm{mL}$ sedangkan rata-rata pada kelompok $\mathrm{P}_{0}$ yaitu 0,155 dengan kadar $0,59 \mathrm{nmol} / \mathrm{mL}$.
Kelompok $\mathrm{P}_{2}$ memiliki rata-rata dan kadar yang lebih tinggi dibandingkan dengan kelompok $\mathrm{P}_{0}$ dimana rata-rata kelompok $\mathrm{P}_{2}$ yaitu memiliki rata-rata 0,231 dengan kadar MDA 1,252 $\mathrm{nmol} / \mathrm{mL}$ sedangkan pada kelompok $\mathrm{P}_{0}$ memiliki rata-rata 0,157 dengan kadarnya $0,402 \mathrm{nmol} / \mathrm{m}$ dan kelompok $\mathrm{P}_{3}$ memiliki 
rata-rata dan kadar yang lebih tinggi dibandingkan dengan kelompok $\mathrm{P}_{0}$ dimana rata-rata kelompok $\mathrm{P}_{3}$ yaitu memiliki rata-rata 0,303 dengan kadar MDA $1,87 \mathrm{nmol} / \mathrm{mL}$ sedangkan pada kelompok $\mathrm{P}_{0}$ memiliki rata-rata 0,157 dengan kadarnya $0,61 \mathrm{nmol} / \mathrm{mL}$. .

Berdasarkan pada hasil diatas pada kelompok kontrol $\left(\mathrm{P}_{0}\right)$ juga terbentuk MDA dalam tubuh. Hal ini sesuai dengan teori bahwa sumber radikal juga bisa berasal dari dalam tubuh yaitu sebagai respon normal dari rantai peristiwa biokimia dalam tubuh. Secara endogen, radikal bebas dapat timbul melalui beberapa mekanisme yaitu autooksidasi, aktivitas oksidasi, sistem transport electron dan lain-lain ${ }^{4}$.

Pada kelompok eksperimen kadar MDA lebih tinggi dibandingkan dengan kelompok kontrol. Hal ini menandakan bahwa paparan asap rokok dapat menyebabkan peningkatan kadar MDA. Hal ini dikuatkan dengan uji ANOVA yang menunjukkan perbedaan yang signifikan antara kelompok kontrol dengan kelompok eksperimen. Radikal bebas dari asap rokok menyebabkan terjadinya peroksidasi asam lemak tak jenuh membran sel yang memperkuat stres oksidatif 5. Rokok dapat meningkatkan kadar MDA secara signifikan pada perokok pasif dan perokok aktif baik terhadap hewan uji tikus maupun manusia ${ }^{6}$. Sehingga akan terjadi peningkatan kadar MDA akibat adanya paparan asap rokok $^{7}$. Meningkatnya konsentrasi lipid peroksida yang terukur menggambarkan gagalnya mekanisme pertahanan antioksidan endogen dalam kehadiran radikal bebas yang berlebih ${ }^{8}$. Hal ini disebabkan paparan stres oksidatif yang lebih tinggi dari ambang batas kemampuan antioksidan endogen sehingga tidak dapat ditanggulangi oleh tubuh dan menyebabkan peningkatan kadar MDA.

Peningkatan kadar MDA pada kelompok ini disebabkan karena kandungan asap rokok yaitu terdiri dari fase partikel dan fase gas. Fase gas asap rokok terbukti menginisiasi autooksidasi in vitro dari PUFA sehingga terjadi peroksidasi lipid. Fase gas asap rokok dapat berisi hingga 1014 radikal bebas dan zat-zat reaktif per kepulan asap rokok. Radikal bebas dan oksidan yang terdapat pada fase gas asap rokok memiliki waktu paruh pendek, namun senyawa tersebut dapat memasuki aliran darah dan menyebabkan kerusakan oksidatif makromolekul. Fase partikel asap rokok mengandung kompleks hidrokarbon yang akan bereaksi dengan nitrogen oksida (NO) dan membentuk senyawa radikal lain. NO yang terdapat pada asap rokok dapat menginisiasi PUFA dan mengakibatkan pembentukan peroksidasi lipid. Fase partikel asap rokok memiliki waktu paruh lebih lama daripada fase gas. Fase partikel mengandung ion logam yang dapat menghasilkan radikal hidroksil dari hidrogen peroksida. Radikal tersebut dapat menembus membran sel dan dapat menginduksi stres oksidatif ${ }^{9}$.

Pada kelompok eksperimen jika dibandingkan maka $\mathrm{P}_{1}$ memiliki nilai rata-rata dan kadar yang terendah yaitu 0,191 dengan kadar 0,904 $\mathrm{nmol} / \mathrm{mL}$ sedangkan kelompok $\mathrm{P}_{2}$ memiliki ratarata yaitu 0,231 dengan kadar MDA $1,252 \mathrm{nmol} / \mathrm{mL}$ dan yang memiliki kadar tertinggi adalah kelompok $\mathrm{P}_{3}$ yaitu memiliki nilai rata-rata 0,303 dengan kadar MDA $1,87 \quad \mathrm{nmol} / \mathrm{mL}$. Pada kelompok $\mathrm{P}_{3}$ menunjukkan peningkatan kadar MDA yang paling tinggi dimana hal ini menyatakan bahwa peningkatan kadar MDA bergantung pada dosedependent relationship yang berarti bahwa kadar MDA akan semakin meningkat seiring peningkatan lamanya paparan asap rokok hal ini terjadi karena jumlah asap rokok yang dipaparkan lebih tinggi dibanding kelompok lain ${ }^{10}$.

Peningkatan kadar MDA yang tinggi menunjukkan adanya proses oksidasi dalam membran sel. Membran sel kaya dengan sumber poly unsaturated 
fatty acid (PUFA) yang mudah dirusak oleh bahan pengoksidasi, proses tersebut dinamakan peroksidasi lemak. Hal ini sangat merusak karena prosesnya berkelanjutan dan terus-menerus. MDA dapat berikatan dengan berbagai molekul biologis seperti protein, asam nukleat, dan amino fosfolipid secara kovalen sehingga dapat menyebabkan terjadinya kerusakan lokal dan disfungsi organ tertentu ${ }^{11}$. Kerusakan yang diinduksi oleh ROS mempunyai peran penting dalam patogenesis penyakit paru kronis, penyakit paru neonatal akut, misalnya sindrom distres pernapasan dan gangguan penyakit lainnya ${ }^{12}$.

\section{KESIMPULAN}

\begin{tabular}{|c|c|}
\hline Peningkatan & MDA \\
\hline nding lurus & waktu \\
\hline yaitu semakin lama & waktu \\
\hline kadar $\mathrm{N}$ & \\
\hline & \\
\hline 8. & \\
\hline $1,252 \mathrm{nmol} / \mathrm{mL}$, dan & \\
\hline
\end{tabular}

\section{DAFTAR PUSTAKA}

[1] Britton, J., and Edwards. F. 2007. Tobacco Smoking, harm reduction, and nicotine product regulation. Lancet.

[2] Brian, Mathew. 2016. Perbedaan kadar malondialdehida pada subyek bukan perokok, perokok ringan dan sedang-berat. JKD vol 5 no 4

[3] Yunus, Moch. 2001. Pengaruh Antioksidan Vitamin C Terhadap MDA Eritrosit Tikus Wistar Akibat Latihan Anaerobik. Jurnal Pendidikan Jasmani.

[4] Febrina L dan Helmi. 2016. Profil Kadar Malondialdehida, Glukosa, dan Kolesterol pada Tikus Putih yang Terpapar Asap Rokok.,J.Trop. Pharm. Chem Vol.3 No.
[5] Kevin, Hannah. 2006. An integrated view of oxidative stress in aging : Basic mechanism, functional effect and pathological considerations. Am J Physiol Regur Integr Comp Physiol

[6] Omar, F.A., \&Wasan, T.A. (2013). Effect of Cigarette Smoking on Lipid Peroxidation And Antioxidant Status in Iraqi Men at Baghdad City. International Journal of Basic and Applied Sciences.

[7] Somwanshi, et all. 2013. Effect of Cigarette Smoking on Serm count and Sperm motility. Journal of Medical Education \& Research.

[8] Balamurugan, M., Parthasarathi, K., Ranganathan, L.S., \& Cooper, E.L. (2008). Hypothetical Mode of Action of Earthworm Extract With Hepatoprotective and Antioxidant Properties. Journal of Zhejiang University Science.

[9] Pryor WA, Dooley MM, Church DF.1985. Mechanisms of cigarette smoke toxicity: the inactivation of human alpha-1-proteinase inhibitor by nitric oxide/isoprene mixtures in air. Chem Biol Interact

[10]Lykkesfeldt 2007. Malondialdehyde as biomarker of oxidative damage to lipids caused by smoking. Clin Chim Acta.

[11]Nielsen, F., Mikkelsen, B.B., Nielsen, J.B., Andersen, H.R., dan Grandjean, P. 1997. Plasma Malondialdehyde as Biomarker for Oxidative Stress: Reference Interval and Effect of Life-style Factors. Journal Clinical Chemistry

[12]Mutiasari, Dian. 2016. Pengaruh lama paparan asap terhadap risiko aterosklerosis melalui pengukuran malonildealdehyde dan advanced oxidation protein product secara invivo. Jurnal Berkala Kesehatan, Vol. 1, No. 2 